\title{
The influx of persons seeking international protection in Poland compared to other EU states during the EU migration crisis (2014-2016)
}

Migrations have been part and parcel of human lives since the dawn of history. People have always migrated in search of shelter, work and better living conditions. Similarly to North America and specifically the United States, Europe has been one of the most popular settlement destinations among migrants. Their movements have brought both advantages and disadvantages. The former include benefits that are economic (such as investment, job creation, trade development, and cheap labor) as well as cultural and scientific (including the enrichment of indigenous cultures and customs, experience exchanges, contributions to knowledge, and opportunities to improve foreign language skills). The disadvantages included irregular immigration, the rise of organized crime, unemployment and an added cost to the state.

In the $21^{\text {st }}$ century, EU member states have become the site of rapid population movements. The exodus they observed was caused primarily by the so-called Arab revival having to do with Arab societies growing increasingly dissatisfied with living conditions, rising corruption in power circles and the spread of nepotism. All this sparked domestic conflicts across Syria, Iraq, Libya and Lebanon. Other drivers of immigration to Europe included economic hardships, troubled politics and human rights violations in Eritrea, internal fighting in Mali, the failing economy of Gambia, the persecution of suspected participants in the December 2014 coup and armed conflicts in Sudan, Pakistan, Afghanistan, the Democratic Republic of the Congo, Somalia and Nigeria.

The article discusses issues related to the EU migration crisis and the influx of international protection seekers to EU countries, including Poland. The author provides a quantitative and geographical analysis of this phenomenon. Consideration is also given to patterns underlying the origin of foreigners seeking refuge in the EU. The author examines figures on applicants for international protection in Poland and the reactions of Polish society to the ensuing crisis. The article covers the period from 2014 to 2016. The 2014 mark was selected to denote the major surge in the flows of international protection seekers into the EU, which precipitated the migration crisis. The ending date was chosen to reflect the availability of statistics for full calendar years and thus to facilitate migration flow comparisons. In exploring the above issues, a number of research questions arose, such as the following: How many people sought international protection in the EU between 2014 and 2016? Where did the refugees originate from? Which countries were the most popular with refugee status seekers? How many people chose to seek safe havens in Poland and how many of them were granted legal 
approval? How willing were Poles to accept refugees from conflict areas? In line with the interdisciplinary approach adopted by the author, a wide range of methods were employed, including decision-making, comparative and statistical methods as well as methods associated with historical sciences.

According to the International Organization for Migration, the number of international migrants world-wide reached an all time peak of 244 million in 2015 (Global, 2016, p. 5). Half of the migrants chose the most popular destinations, i.e. the USA (46.6 million), Germany (12 million), Russia (11.9 million), Saudi Arabia (10.2 million) and the United Kingdom ( 8.5 million) (ibid.). The year 2015 turned out to bring an unprecedented number of people seeking safe haven abroad. The rates during that year were the highest since the end of World War II.

While certain migration flow increases were detected as early as 2013 (from 2012), they became significantly steeper in the years that followed and especially from 2014 to 2015 , when the numbers of applicants for refugee status swelled by 627,860 . The level of applications remained high throughout 2016, albeit short of the 2015 record.

\section{Figure 1. Applicants for refugee status in EU countries from 2011 to 2016}

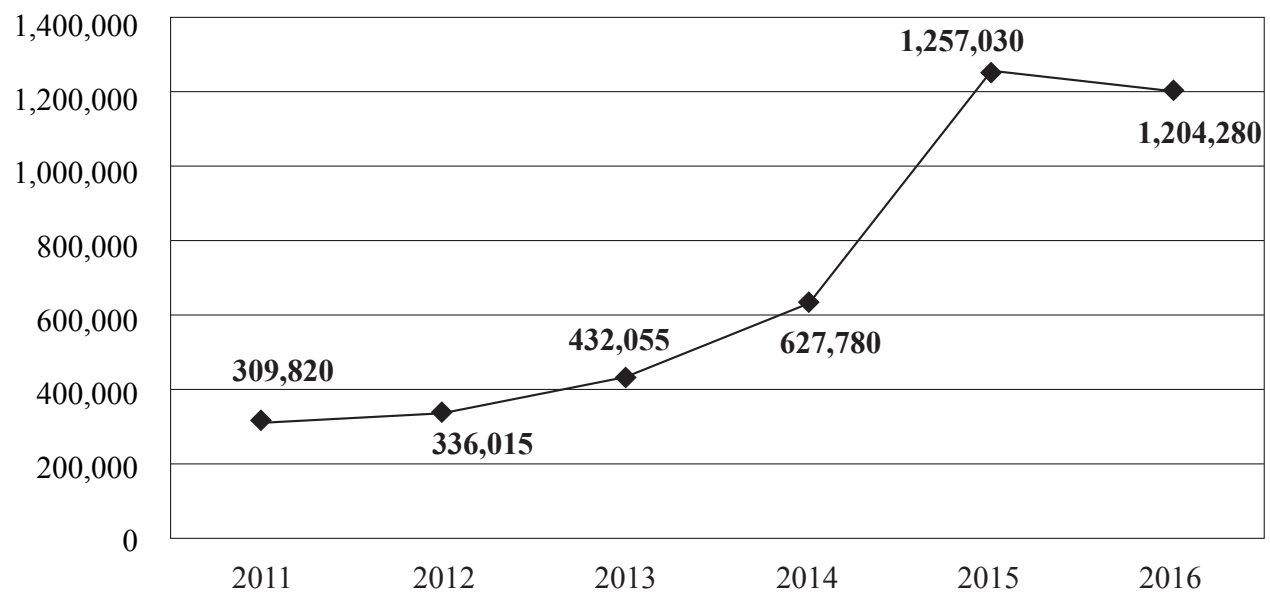

Source: Own research based on Asylum and new asylum applicants - annual aggregated data (2016a), Eurostat, http://ec.europa.eu/eurostat/tgm/table. do?tab=table \&init=1\&plugin=1\&pcode=tps00191\&language=en, 17.02.2016; Asylum in the EU Member States - Record number of over 1.2 million first time asylum seekers registered in 2015. Syrians, Afghans and Iraqis: top citizenship, Eurostat Newsrelease (2016c), 44/2016, 4 March 2016, Eurostat, http://ec.europa.eu/eurostat/documents/2995521/7203832/304032016-AP-EN.pdf/790eba01-381c-4163-bcd2-a54959b99ed6, 20.03.2016; Asylum in the EU Member States - 1.2 million first time asylum seekers registered in 2016. Syrians, Afghans and Iraqis continued to be the top citizenship, Eurostat Newsrelease (2017), 46/2017, Eurostat, http://ec.europa.eu/eurostat/documents/2995521/7921609/3-16032017-BP-EN.pdf/e5fa98bb-5d9d-4297-9168-d07c67d1c9e1, 20.07.2017.

Migrants streamed into Europe by many routes. These included the Western, Eastern and Central Mediterranean, the Western Balkans and Murmansk (Adamczyk, 2016, p. 42). Migrants arrived by land as well as by sea. Many did not survive the ordeal. In 2015, at least an estimated 5,740 immigrants lost their lives or disappeared en route (Global, 2016, p. 14). According to the International Organization for Migra- 
tion (IOM), an estimated 3,771 people drowned in the Mediterranean (Over, 2015). In 2016, deaths at sea swelled to 7,763 worldwide as a large proportion of migrants fled from Libya via the Mediterranean Sea to Italy. This represented a 27\% increase on the preceding year and a 47\% increase from 2014 (Migrant, 2017). 5,085 people drowned in the Mediterranean in 2016 (ibid.). This means that the sea consumed an average of 14 human lives every day (Quinn, 2016).

\section{Map 1. Primary migration routes across the Mediterranean}

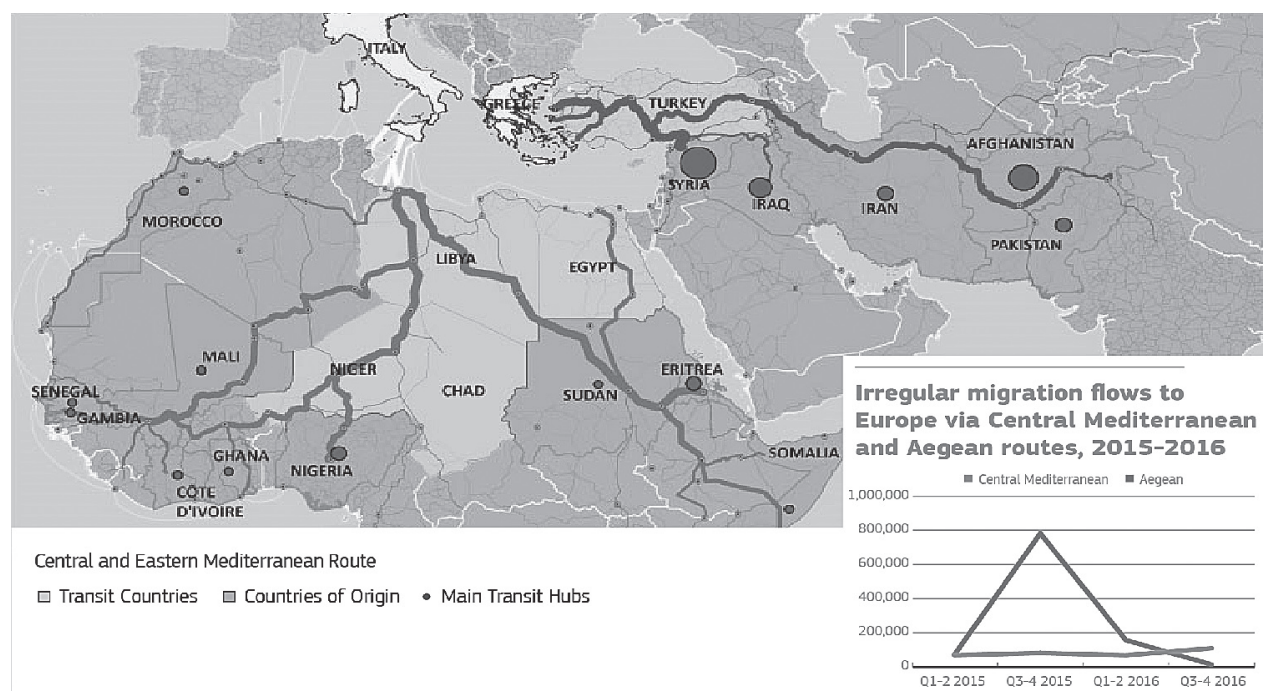

Source: Irregular Migration via the Central Mediterranean (2017), European Political Strategy Centre, 2 February 2017, p. 5, http://ec.europa.eu/germany/sites/germany/files/pepsc_strategic_notes_irregular migration.pdf, July 12, 2017.

In 2015, the majority of the migrants arriving in Europe via the Mediterranean headed for Greece. Over the span of that year, Greece was selected by 853,650 immigrants. Italy was the second most popular destination with a total of 153,842 migrants. Among other destinations, 3,845 migrants chose Spain and 106 Malta (Mediterranean, 2017, Over, 2015). The trend shifted in 2016 as more migrants chose Italy than Greece. While the former absorbed 181,436 people, the latter saw 173,561 arrivals (Mediterranean, 2017). The trend then continued in 2017. As of August 14, 2017, 97,241 protection seekers made their way to Italy compared to 12,440 arrivals in Greece (Mediterranean Situation, 2017).

Before the migration crisis struck Europe, from 2008 to 2011 France was the most popular destination with foreign refuge seekers. Germany, which was second at the time, became the prime destination in the following years, including 2014. During that year, $31 \%$ of all individuals seeking refugee status in the EU $(172,945)$ filed their applications in Germany. Next in the destination popularity ranking was Sweden (with 74,980 applicants), followed by Italy $(63,655)$ and France $(58,845)$ (Asylum, 2016c). During the peak year for the influx of international protection seekers, Germany remained in the lead. At that time, as many as 441,800 applicants sought refugee status 
in that country (accounting for $35 \%$ of all EU applications). Other popular destinations included Hungary (174,435 or 14\%), Sweden (156,110 or 12\%), Austria and Italy (7\% each) (Asylum, 2016c, p. 2). Notably, the highest 2014-to-2015 increase in refugee status applications country-wide was observed in Finland (up by $822 \%$ ), followed by Hungary (323\%), Austria (233\%) and Belgium (178\%, ibid.). In 2016, destination choice patterns changed markedly, albeit without affecting Germany, which remained in the lead. In fact, Germany became even more popular, posting a $63 \%$ increase in applications on 2015 (up from 441,800 to 722,265 ). Germany received a total of $60 \%$ of all asylum applications in the EU (Asylum, 2017, p. 4). Elsewhere, Italy $(121,185$ or $10 \%)$ and France $(75,990$ or $6 \%)$ were the most popular destinations (ibid.). In 2016, the sharpest year-on-year increases in refugee status applications by country were recorded in Croatia (up by 1,413\%), Slovenia (up by 389\%) and Greece (up by $339 \%$ ). Meanwhile, the biggest drops were observed in the Scandinavian countries of Denmark (down by $71 \%$ ), Sweden (down by $86 \%$ ) and Finland (down by $84 \%$ ). Declines were also seen in Hungary, down by $84 \%$, and Belgium, down by $63 \%$ (ibid.).

From 2014, the greatest number of international protection applications was lodged by Syrian and Afghan nationals. In 2014 alone, Syrians lodged 122,790 applications, accounting for $20 \%$ of the overall filings. 2015 saw three times more applications $(362,775)$, setting records in the three-year period since 2014. 2016 saw the number of applications decrease slightly to 334,820 (Asylum, 2015, p. 4, Asylum, 2016c, p. 3, Asylum, 2017, p. 2). The majority of the applications filed by Syrians were made in Germany. According to the International Organization for Migration, Syrian asylum seekers in Europe were predominantly young (28 years of age on average, $74 \%$ ), well educated, migrating in groups (87\%) and migrating with family members (73\%) (Adamczyk, 2016, p. 47).

The second largest number of asylum applications filed in the EU came from the citizens of Afghanistan. In 2015, their number rose more than fourfold on the preceding year (from 41,305 in 2014 to 178,230 in 2015). 2016 saw the number of Afghan applicants climb slightly to $15 \%$ of the total number of applicants for international protection (Asylum, 2015, p. 4, Asylum, 2016c, p. 3, Asylum, 2017, p. 2). On the receiving end, Germany attracted the most applications for refugee status. Other top host countries included Hungary and Sweden. Similarly to the Syrians, the majority of Afghan immigrants were young (24 years of age on average) males (86\%), also traveling in groups (Adamczyk, 2016, p. 47). The third largest number of refugee applicants in 2014 came from Kosovo $(37,875,6 \%)$. The majority of them (57\%) lodged their applications in Hungary (Asylum, 2015, p. 4). In the following years, Kosovo nationals were replaced by the Iraqis (121,535 in 2015 and 126,955 in 2016). The Iraqis' most popular state of first asylum application was Germany (Asylum, 2015, p. 4, Asylum, 2016c, p. 3, Asylum, 2017, p. 2).

The nationals of 28 member states who participated in a survey commissioned by the European Parliament in September 2015 (i.e. before the Paris attacks) considered the flow of new refuge seekers as one of the central issues affecting the EU. They put migrations as the second most crucial issue (ahead of combating unemployment) in their ranking of the challenges faced by the Union (Gtówne wyzwania, 2015). Such an opinion was expressed by $47 \%$ of the respondents (ibid., p. 2). The majority of them 
$(66 \%)$ were in favor of having the EU act jointly on migration policy and financially support the member states that experienced the brunt of migration impact ( $62 \%$ - ibid., p. 4). EU respondents further argued that legal migration procedures should be made "uniform" across all member states (79\% - ibid., p. 4). In their opinion, asylum seekers should be better distributed among the member states $(78 \%)$, while the related decisions should be made at the EU level based on "binding quotas" (78\% - ibid., p. 5).

Reactions to the uncontrolled influx of migrants into the EU varied widely. Some countries (Hungary, Slovenia, Austria, and Macedonia) put up fences along their borders while others set up temporary border controls (Germany, Denmark, Sweden, Austria, Slovenia, Croatia), modified their asylum laws, reduced refugee benefits and established local and civil guards (Germany, Finland, Hungary). Hungary chose to proclaim "a mass migration crisis" in its individual committees (or regions). By March 2016, the crisis zone was expanded to cover the entire country. Protests broke out in many European cities, both for and against migrations. Assaults on foreign nationals became more frequent.

To address the challenges brought about by migrations into its territory, the EU took a number of initiatives. These included the resettlements, relocations and removals of illegal migrants. The effort was part of the migration policy derived from Arts. 79 and 80 of the Treaty on the Functioning of the European Union (Consolidated versions, 2012). Article 80 thereof provided for the migration policy to be based on the principle of "solidarity and fair sharing of responsibility, including its financial implications, between the Member States" (ibid.). Life showed just how fragile such solidarity really was. The principle was respected mainly by the so-called old EU member states and much less readily by the new ones. The discrepancy resulted, among other things, from the fact that the former had a long history of being immigrant destinations and, as such, were better prepared to receive foreigners. In addition, their longer memberships of the EU have prepared them better to responsibly handle the crisis in keeping with EU values. Their long-standing cooperation has solidified their mutual solidarity allowing them to act more consistently than the socalled new members of the EU.

According to a European-Parliament-commissioned survey of 28 EU member states conducted in March 2017, the majority of the respondents rated the EU's measures on migration to be insufficient (58\%). Only $26 \%$ considered them adequate and $9 \%$ excessive, with 7\% admitting to having no opinion on the matter (Nancy, 2017, p. 25). The nations most likely to believe that the EU's response was insufficient were Estonians (87\%), Italians (76\%) and Bulgarians (73\%). Meanwhile, Luxembourgians (41\%), the British (43\%), Finns and Danes (44\% each) were the least likely to complain about the issue (ibid., p. 29).

Few refugees found Poland to be an attractive destination. Between 2014 and 2016, the share of applications the country received relative to the EU's total ranged from $0.98 \%$ to $1.3 \%$. During these three years, the lowest number of refugee applications was submitted in 2014 (8,193), while the highest $(12,323)$ came in 2015 . The year 2014 was comparable to 2015 in which 12,319 applicants made their asylum filings. Whilst in the EU as a whole, the number of applications increased by 627,860 from 2014 to 2015, the rise in Poland amounted to 4,130. In comparison, the two most popular des- 
tination countries saw increases by 268,855 (Germany) and 133,220 (Hungary). ${ }^{1}$ Thus, Poland never got to experience the kind of migration crisis that hit the EU and that was actually limited to selected member states. Neither did the breakdown of asylum applicants ending up in Poland by the country of origin coincide with the EU-wide trend. While migrants in Europe were predominantly Syrian, Afghan and Iraqi, those coming to Poland were mostly Russian, Ukrainian and Tajikistani (as well as Georgian in 2014).

In addition to the refugee status, Poland offered the option of seeking asylum. Under the Polish law, asylum is governed by Art. 56.1 of the Constitution of the Republic of Poland of 1997 and by Art. 90.1 of the Act of June 13, 2003 on granting protection to foreigners in the Republic of Poland (Ustawa, 2003). Under the law, asylums may be granted to applying foreign nationals if and where they are "necessary for their protection without jeopardizing the vital interests of the Republic of Poland" (ibid.). Few immigrants arriving in Poland ever chose to apply for asylum. ${ }^{2}$ In the years 2008-2014, for instance, their numbers fluctuated between none and five per year. No significant increases were observed prior to 2015. During that year, asylum applications in Poland were filed by 118 foreigners, up from a mere 4 applications during the preceding year. By 2016, the number of applications dropped to 23 (Zestawienie, 2016). In 2015, most applications were made by Ukrainians (111, or $94 \%$ of the total). Other applicants were Russian (4), Bangladeshi, Egyptian and Tunisian (1 person each) (Dane, 2015). In 2016, the statistics were still led by Ukrainians (10 out of 23 applications), followed by Russians (5), Belarusians (4), Georgians (2), Libyans and Vietnamese (Zestawienie, 2016).

In addition to the above opportunities, foreigners in Poland had the option of applying for subsidiary or temporary protection (Article 3.1 of the Act, 2003). Subsidiary protection can be extended to foreign nationals who have not received refugee status but are unable to return to their country without running the risk of being seriously harmed (by e.g. being sentenced to death or subjected to execution or torture; Article 15 of the relevant Act, 2003). Temporary protection is available to foreigners who have come to Poland in large numbers fleeing an invasion, a war, a civil war, an ethnic conflict or gross human rights violations (Article 106.1 of the Act, 2003). Such protection may be granted for a period of up to 12 months with renewal available for up to two additional 6-month periods. Foreign nationals may extend their stay in Poland if they are unable to return safely to their previous place of residence or need to undergo in-patient treatment. There have been no cases in Poland of applying this rule.

Only a handful of applications for international protection have been approved during the study period. Very few individuals in Poland received refugee status between 2014 and 2016. The share of application approvals (first or second instance decisions) ranged from $1 \%$ in 2016 to $4.5 \%$ in 2014. 755 migrants (out of a total of 32,837 applicants) were granted refugee status in Poland during the three-year period. The majority

\footnotetext{
${ }^{1}$ Own calculations based on Eurostat data.

${ }^{2}$ For more, see Adamczyk A. (2012), Społeczno-polityczne implikacje imigracji do Polski w latach 1989-2007, Poznań, pp. 182-185.
} 
of them were the nationals of Syria (358), Russia (49) and Iraq (35). ${ }^{3} 45$ other successful refugee status applicants were stateless. Meanwhile, the asylum status in Poland was granted to 110 foreigners. It is worth noting that not a single person received such status between 2001 and 2014. This did not change until 2015 when the asylum was given to, among others, 109 Ukrainians and one Russian citizen (Dane, 2015; Zestawienie, 2016).

The foreign nationals offered protection in Poland also include individuals who have received approvals for subsidiary protection. Such protection was extended to a total of 574 persons in 2014-2016, 55\% of whom were Russian citizens. The nationalities with the next highest number of successful applicants were Iraqis and Ukrainians. Poland was also home to migrants who were granted either an authorization to stay for humanitarian reasons or the so-called tolerated stay permit. The power to award the former rests, among others, with commanders of Border Guard units and stations. It may be granted to migrants whose removal to their country of origin would:

- put them at risk of suffering torture, forced labor or being deprived of the right to a fair trial;

- result in withholding their right to family or personal lives;

- result in violations of the rights of children (Article 348.1 of the Foreign Nationals Act, 2013).

According to the Office for Foreigners, 12 individuals (including 6 Armenians) received such protection in 2015, followed by 15 individuals in 2016 ( 5 of whom were Ukrainian and 4 from Madagascar).

Tolerated stay permits were granted to aliens who had been denied the authorization to stay for humanitarian reasons and those whose removal:

- "was found unfeasible for reasons beyond the control of the authority responsible for enforcing the decision to remove the foreign national and beyond the control of such a national, or

- could only be made to a state to which such a removal was held inadmissible by a court decision or a decision of the Minister of Justice refusing to render the concerned foreign nationals" (Article 348 of the Foreign Nationals Act, 2013).

Between 2014 and 2016, 602 people were granted a tolerated stay permit (390 in 2014, 139 in 2015 and 73 in 2016). The top citizenships among them were Russians (355 individuals or 59\%), Georgians (53), Ukrainians (46) and Armenians (42). All in all, between 2014 and 2016, Poland granted one form of international protection or another to a total of 2,086 immigrants. It is nevertheless unclear how many of them remained in the country and how many chose to leave. This notwithstanding, the figures are merely symbolic compared to those seen in other EU countries.

It is notable that certain representatives of the Polish government refused to acknowledge the above statistics. Instead, they maintained that Poland had received a vast number of persons in need of international protection. One such government representative was Prime Minister Beata Szydło. During a debate in the European Parliament held on January 19, 2016 in Strasbourg, Szydło claimed that Poland had

${ }^{3}$ Own calculations based on statistics from the Office for Foreigners, https://udsc.gov.pl/statystyki/raporty-okresowe/zestawienia-roczne/, 17.07.2017. 
accepted approximately one million refugees from Ukraine (Beata Szydto, 2016). Subsequently, at the Davos forum on January 22, 2016, Development Minister Mateusz Morawiecki told journalists that Poland had accepted 350,000 refugees from Ukraine between 2014 and 2015. This, in his view, made it second only to the UK in terms of the total number of migrants admitted per capita (Najpierw, 2016). During a panel debate on the refugee crisis at the World Economic Forum in Davos, Foreign Minister Witold Waszczykowski said "...we host about one million Ukrainians in Poland" (W Davos, 2016). Unlike in his prior statements, the minister refrained from using the word refugee in reference to Ukrainian visitors.

Out of the small number of immigrants admitted by Poland during the period in question, the Polish authorities have so far refused to accept a single foreigner under the relocation mechanism. All in all, 6,182 people in need of international protection were to come to Poland, as set forth in the Resolution of July 20, 2015, which obliged the country to admit 1,100 persons (Outcome 2015, pp. 4-5) and in EU Council Decision 2015/1601, which referred to a further 5,082 individuals (Annexes, 2015).

Other than Poland, two other countries, i.e. Hungary and the Czech Republic, ${ }^{4}$ failed to deliver on their obligations. This prompted the European Commission to launch an EU infringement proceeding on June 14, 2017 (Relokacja, 2017). Responding to a request from the European Commission in July 2017, the Polish Minister of Internal Affairs and Administration appealed for the discontinuance of the EU infringement proceeding in view of the relocation decisions of 2015. In a justification on the stance he took, the Minister referred to, among others, "systemic deficiencies in the mechanism of enforcing relocation decisions that failed to incorporate adequate security guarantees" (Minister, 2017).

The delivery on the relocation commitments assumed in the EU turned out to be very sluggish. As of July 24,2017 , only $25 \%$ of the people in need of international protection $(24,676)$ were relocated from Italy and Greece. Malta, the best performer, which relocated 137 individuals out of the total of 131 pledged, was followed by Finland (87\%), Ireland (76.5\%), Latvia (67\%), and Luxembourg (59\%, Annex, 2017). According to relocation reports, the so-called old EU member states demonstrated a better understanding of the principle of solidarity by relocating more migrants from Greece and Italy than the so-called new EU states. ${ }^{5}$

Poland's reluctance to accept immigrants during the period in question resulted in part from changes in the country's migration policy. The government of the Law and Justice party focused on home security, and established a coalition of countries opposed to relocations and a system favoring immigrants stemming from Poland's eastern neighborhood countries, which incorporated facilitations for foreigners of Polish descent (Adamczyk, 2017a, p. 313). The authorities chose to address the resettlement issue primarily by amending national legislation and revamping the country's institutional framework. The approach adopted by the Polish government and the rhetoric that resounded in statements on the reception of immigrants had its impact on the views of Poland's general public on the relocation and treatment of refugees.

${ }^{4}$ The Czechs admitted 12 persons from Greece but none from Italy (as of July 24, 2017).

5 To learn more, see: Adamczyk A. (2017b), Solidarność europejska a relokacja osób wymagajacych ochrony międzynarodowej, „Przegląd Zachodni”, issue 2, pp. 41-61. 
Figure 2. Persons requiring international protection relocated from Greece and Italy by EU country on July 24, 2017

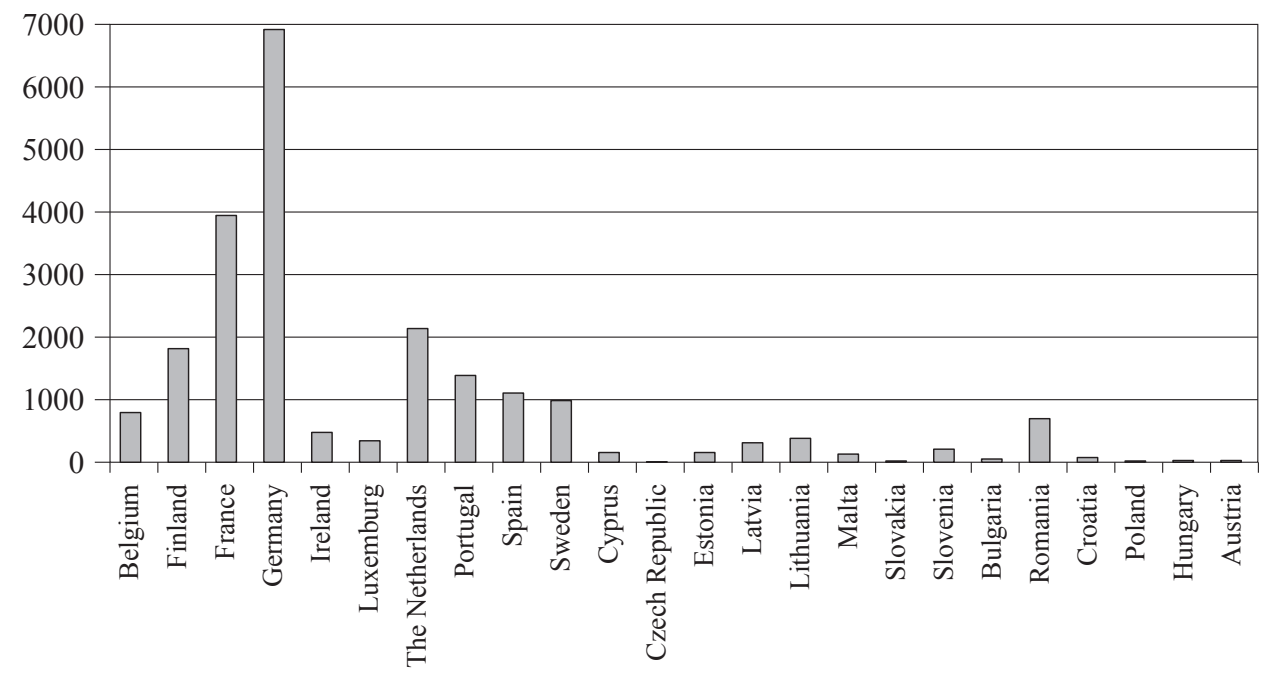

Source: Own research based on Annex to the Report from the Commission to the European Parliament, the European Council and the Council. Fourteenth report on relocation and resettlement, Brussels, July 26, 2017, https://ec.europa.eu/home-affairs/sites/homeaffairs/files/what-we-do/policies/european-agendamigration/20170412_eleventh_report_on_relocation_and_resettlement_annex_3_en.pdf, August 10, 2017.

Figure 3. Poles' views on the admission of refugees from conflict areas during selected periods from May 2015 to December 2016

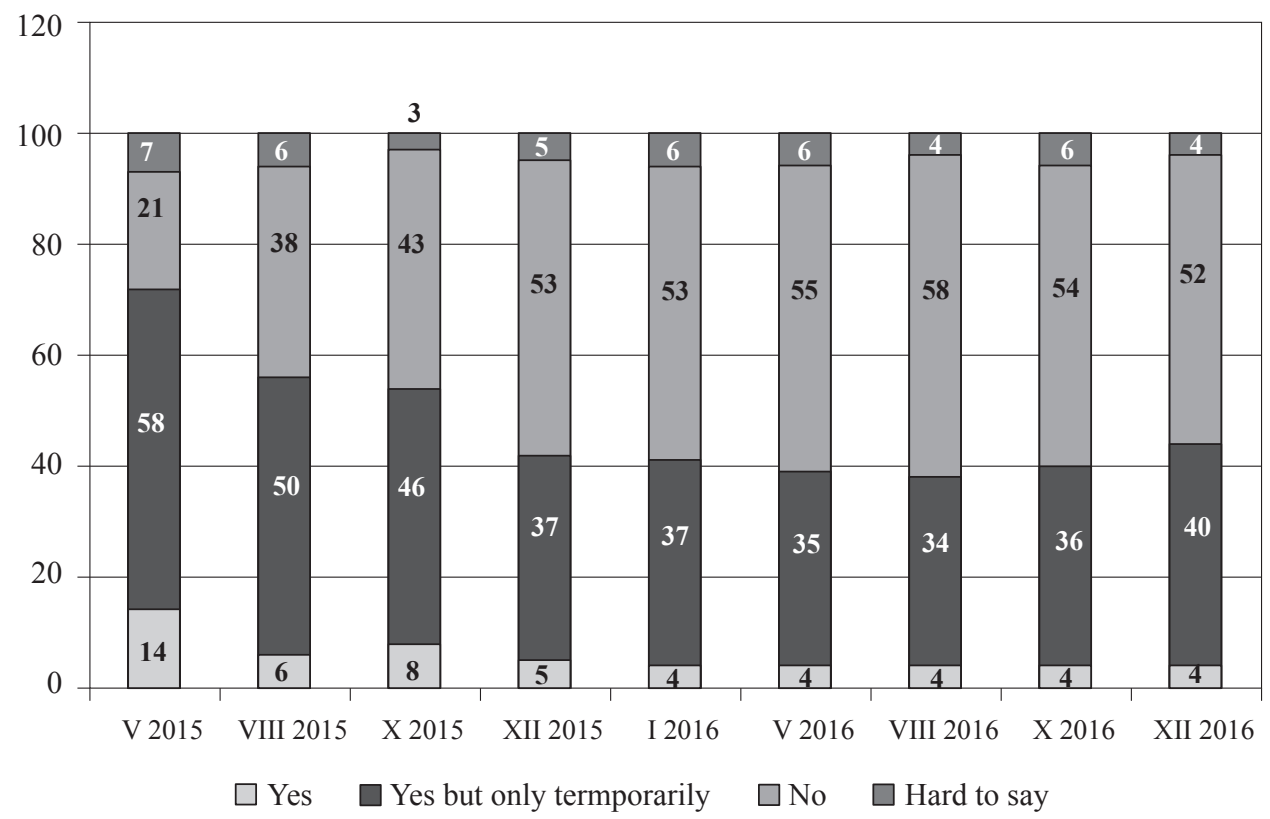

Source: Stosunek Polaków do przyjmowania uchodźców (2017), A. Głowacki, CBOS Komunikat z badań nr 1, Warsaw, p. 2. 
According to the above survey conducted by the Center for Public Opinion Research, Poles showed limited willingness to admit people fleeing armed conflict areas. Acceptance rates, which peaked in May 2015, plateaued at 4\% throughout 2016. The respondents who supported the acceptance of refugees additionally favored their settlement in Poland. Meanwhile, more than $50 \%$ of the respondents between December 2015 and December 2016 opposed such admission. Consent to extending temporary protection reached its high in May 2015, with 58\% of the respondents favoring this option. By 2016, support for the solution dropped to $34-40 \%$ of the respondents.

Poles expressed their likes and dislikes by demonstrating in the streets or painting murals. Another way of showing their views on immigrants was through posters. For example, in the town of Mińsk Mazowiecki, a poster appeared with the fairly controversial slogan: "For the sake of the European Union, do not scream too loud when a refugee rapes you." The poster campaign was the work of local activists of the Korwin party (Kontrowersyjne, 2016). The Internet has also become an important forum on which Poles anonymously expressed their views on the refugee crisis and the migrants themselves. In 2015 and in the first quarter of 2016, the reports on hate incidents posted on the website of the Otwarta Rzeczpospolita Association included those on calls for the extermination of refugees or the incitement of violence against them. Most Internet users expressed their views via Facebook. The site was also used to announce events. A number of theme pages were created, such as "No to Muslim immigrants from Africa in Poland" or "Resolute NO to African refugees." In addition, there were also pages that welcomed the admission of immigrants. These included "Yes to refugees in Poland" and "Yes to refugees. No to racism and xenophobia."

The migration crisis never affected Poland. The influx of people seeking international protection in the years 2014-2016 was meager compared to that seen in other EU member states. Such limited interest in coming to Poland could be due to the lack of a so-called migrant network and the consequent failure to create a "migration chain" (Adamczyk, 2012, p. 37). Moreover, the Polish state was unable to provide the kind of social assistance that was available to refugees in other countries (e.g. Germany). Also of significance was the Polish government's stance on accepting persons in need of protection under relocation schemes, the changed priorities of the Polish migration policy, and the reluctance to harboring foreigners on the part of a sizable segment of Polish society.

Evidently, the admission of migrants to Poland has become selective. Preference has been given to persons that the country needed for economic reasons. Meanwhile, Poland tended to turn away those seekers of help and refuge who, in the words of Zygmunt Bauman, performed no "useful function" (Bauman, 2007, p. 60).

\section{Bibliography}

Adamczyk A. (2016), Kryzys imigracyjny w UE i sposoby jego rozwiazania, "Przegląd Politologiczny", nr 3.

Adamczyk A. (2017a), Kryzys migracyjny w Europie a polska polityka imigracyjna, "Studia Migracyjne - Przegląd Polonijny", nr 1.

Adamczyk A. (2017b), Solidarność europejska a relokacja osób wymagajacych ochrony międzynarodowej, "Przegląd Zachodni”, nr 2. 
Adamczyk A. (2012), Społeczno-polityczne implikacje imigracji do Polski w latach 1989-2007, Poznań.

Annexes to Council Decision (EU) 2015/1601 of 22 September 2015 establishing provisional measures in the area of international protection for the benefit of Italy and Greece (2015), Official Journal EU L 2015.248.80.

Annex to the Report from the Commission to the European Parliament, the European Council and the Council. Fourteenth report on relocation and resettlement, Brussels, 26.07.2017, https:// ec.europa.eu/home-affairs/sites/homeaffairs/files/what-we-do/policies/european-agendamigration/20170412_eleventh_report_on_relocation_and_resettlement_annex_3_en.pdf, 10.08.2017.

Asylum and new asylum applicants - annual aggregated data (2016a), Eurostat, http://ec.europa. $\mathrm{eu} /$ eurostat $/ \mathrm{tgm} /$ table.do? tab $=$ table \&init $=1 \&$ plugin $=1 \&$ pcode $=$ tps $00191 \&$ language $=e n$, 17.02.2016.

Asylum in the EU. The number of asylum applicants in the EU jumped to more than 625000 in 2014. 20\% were Syrians (2015), Eurostat Newsrelease, 53/2015, Eurostat, http://ec.europa.eu/ eurostat/documents/2995521/6751779/3-20032015-BP-EN.pdf/35e04263-2db5-4e75-b3d36b086b23ef2b, 15.07.2017.

Asylum in the EU. Member States record number of over 1.2 million first time asylum seekers registered in 2015. Syrians, Afghans and Iraqis: top citizenship (2016c), Eurostat Newsrelease, 44/2016, 4 March 2016, Eurostat, http://ec.europa.eu/eurostat/documents/2995521/7203832/304032016-AP-EN.pdf/790eba01-381c-4163-bcd2-a54959b99ed6, 20.03.2016.

Asylum in the EU Member States. 1.2 million first time asylum seekers registered in 2016. Syrians, Afghans and Iraqis continued to be the top citizenship (2017), Eurostat Newsrelease, 46/2017, Eurostat, http://ec.europa.eu/eurostat/documents/2995521/7921609/3-16032017BP-EN.pdf/e5fa98bb-5d9d-4297-9168-d07c67d1c9e1, 20.07.2017.

Bauman Z. (2007), Plynne czasy. Życie w epoce niepewności, Warszawa.

Beata Szydło na zakończenie. To ważna debata dla Polski i dla Parlamentu Europejskiego. Serdecznie dziękuję [Beata Szydło in closing. A crucial debate for Poland and the European Parliament. Thank you so much] (2016), http://www.tvn24.pl/wiadomosci-ze-swiata,2/parlamenteuropejski-o-polsce-debata-w-strasburgu,612043.html, 20.07.2017.

Consolidated versions of the Treaty of the European Union and the Treaty on the functioning of the European Union (2012), Official Journal EU C 2012.326.1.

Dane liczbowe dotyczące postępowań prowadzonych wobec cudzoziemców w 2016 roku, Urząd ds. Cudzoziemców [Statistics on proceedings involving foreign nationals in 2016], https://udsc. gov.pl/statystyki/raporty-okresowe/zestawienia-roczne/, 20.07.2017.

Global Migration Trends 2015. Factsheet, IOM's Global Migration, Data Analysis Centre, GMDAC, http://gmdac.iom.int/global-migration-trends-factsheet, 20.07.2017.

Irregular Migration via the Central Mediterranean (2017), European Political Strategy Centre, 2 February 2017, http://ec.europa.eu/germany/sites/germany/files/pepsc_strategic_notes_irregular_migration.pdf, 12.07.2017.

Kontrowersyjne plakaty w Mińsku Mazowieckim. „Nie krzycz zbyt głośno, gdy gwałci cię uchodźca” [Controversial posters in Mińsk Mazowiecki. "Do not scream too loud when a refugee rapes you"] (2016), http://wawalove.pl/Kontrowersyjne-plakaty-w-Minsku-Mazowieckim-Niekrzycz-zbyt-glosno-gdy-gwalci-Cie-uchodzca-a21507, 23.02.2016.

Konstytucja Rzeczypospolitej Polskiej z dnia 2 kwietnia 1997 roku, Dz. U. 1997, Nr 78, poz. 483.

Mediterranean Migrant Arrivals Top 363,348 in 2016; Deaths at Sea: 5,079 (2017), https://www. iom.int/news/mediterranean-migrant-arrivals-top-363348-2016-deaths-sea-5079, 6.01.2017.

Mediterranean Situation (2017), http://data2.unhcr.org/en/situations/mediterranean, 6.07.2017.

Migrant Deaths and Disappearances Worldwide: 2016 Analysis (2017), https://www.iom.int/news/ migrant-deaths-and-disappearances-worldwide-2016-analysis, 17.03.2017. 
Minister Mariusz Błaszczak podpisat odpowiedź na zarzuty Komisji Europejskiej w sprawie mechanizmu relokacji [Minister Mariusz Błaszczak signs response to European Commission charges regarding relocation mechanism] (2017), https://mswia.gov.pl/pl/ aktualnosci/16327,Minister-Mariusz-Blaszczak-podpisal-odpowiedz-na-zarzuty-KomisjiEuropejskiej-w-.html?search=510346, 13.07.2017.

Najpierw Szydło, a teraz Morawiecki: ,,350 tys. uchodźców z Ukrainy”. Wpadka czy świadoma narracja rzqdu? Komisja wszczyna postępowanie w sprawie uchybienia zobowiqzaniom państwa członkowskiego wobec Polski, Republiki Czeskiej i Węier [First Szydło, now Morawiecki: "350,000 refugees from Ukraine". Blooper or deliberate narrative by government?] (2016), http://wiadomosci.gazeta.pl/wiadomosci/1,114871,19515665, najpierw-szydlo-a-terazmorawiecki-350-tys-uchodzcow-z-ukrainy.html?lokale=poznan\#BoxNewsImg, 5.06.2017.

Nancy J. (2017), Two years until the 2019 European elections. Special Eurobarometer of the European Parliament, http://www.europarl.europa.eu/RegData/etudes/STUD/2017/599336/ EPRS_STU(2017)599336_EN.pdf, 6.07.2017.

Outcome (2015) of the Council Meeting. 3405th Council meeting - Justice and Home Affairs, Brussels, 20 July 2015, Council of the European Union 11097/15.

Over 3,770 Migrants Have Died Trying to Cross the Mediterranean to Europe in 2015 (2015), IOM, http://www.iom.int/news/over-3770-migrants-have-died-trying-cross-mediterraneaneurope-2015, 5.02.2016.

Quinn B., Migrant Death Toll passes 5000 after two boats capsize off Italy, "The Guardian" 23 December 2016, https://www.theguardian.com/world/2016/dec/23/record-migrant-death-tolltwo-boats-capsize-italy-un-refugee, 13.07.2017.

Relokacja (2017): Komisja wszczyna postępowanie w sprawie uchybienia zobowiqzaniom państwa członkowskiego wobec Polski, Republiki Czeskiej i Wegier [European Commission launches proceeding on member state commitment violations against Poland, the Czech Republic and Hungary], Brussels, June 14, 2017, European Commission Press Release, http://europa.eu/ rapid/press-release_IP-17-1607_pl.htm, 16.06.2017.

Stosunek Polaków do przyjmowania uchodźców (2017), Głowacki A., CBOS Komunikat z badań nr 1, Warszawa.

The main challenges for the EU, migration and the economic and social situation, Parlemeter 2015 - Part I (2015), Brussels 14.10.2015, European Parliament Eurobarometer (EB/EP 84.1), http://www.europarl.europa.eu/pdf/eurobarometre/2015/2015parlemeter/EB84.1_synt_conso_pl.pdf, 2.02.2016.

Ustawa z dnia 12 grudnia 2013 r. o cudzoziemcach (2013), Dz. U. 2016, poz. 1990.

Ustawa z 13 czerwca 2003 r. o udzieleniu cudzoziemcom ochrony na terytorium Rzeczypospolitej Polskiej (2003), Dz. U. 2016, poz. 1836.

W Davos o kryzysie migracyjnym. Debata z udziałem ministra Waszczykowskiego (2016), http:// fakty.interia.pl/raporty/raport-imigranci-z-afryki/informacje/news-w-davos-o-kryzysie-migracyjnym-debata-z-udzialem-ministra-wa,nId,2078571, 17.06.2017.

Zestawienie liczbowe dotyczqce postępowań prowadzonych wobec cudzoziemców w 2016 roku [Statistics on proceedings involving foreign nationals conducted in 2016], Urząd ds. Cudzoziemców, https://udsc.gov.pl/statystyki/raporty-okresowe/zestawienia-roczne/, 17.06.2017.

\section{Summary}

The article discusses issues related to the EU migration crisis of 2014-2016. It offers a quantitative analysis of refugee flows to EU countries, including Poland. The article presents the response of individual EU states to the influx of persons seeking international protection 
post 2014 and the attempts to tackle the immigration problem at the EU level. It focuses on the refugee influx into Poland and examines the origins and numbers of persons who received international protection during the period in question under various legal decisions.

Key words: migration crisis, refugees, European Union, international protection in Poland

\section{Napływ osób poszukujących ochrony międzynarodowej do Polski na tle państw UE w okresie kryzysu migracyjnego w UE (2014-2016)}

\section{Streszczenie}

Przedmiotem rozważań niniejszego artykułu są zagadnienia związane z kryzysem migracyjnym w UE w latach 2014-2016. W artykule została dokonana analiza ilościowa zjawiska uchodźctwa do państw UE, w tym i Polski. W artykule przedstawiono reakcję społeczeństw poszczególnych państw unijnych na napływ osób poszukujących ochrony międzynarodowej po 2014 roku oraz próby rozwiązania problemu imigracyjnego na poziomie UE. Uwypuklono w nim zjawisko napływu do Polski osób szukających schronienia oraz przeanalizowano pochodzenie i stan liczebny osób, które w badanym okresie otrzymały ochronę międzynarodową na podstawie różnych decyzji prawnych.

Słowa kluczowe: kryzys migracyjny, uchodźcy, Unia Europejska, ochrona międzynarodowa w Polsce 
